\title{
Biochemical pathways of arsenic uptake from the environment to human cells
}

\author{
Anna Kowalczyk ${ }^{1,2}$ and Dariusz Latowski ${ }^{1 *}$ \\ ${ }^{1}$ Department of Plant Physiology and Biochemistry, Faculty of Biotechnology, Biochemistry and Biophysics, Jagiellonian University, Gronostajowa 7, 30-387, \\ Krakow, Poland \\ ${ }^{2}$ Department of Environmental Protection, Faculty of Geology, Geophysics and Environmental Protection, AGH University of Science and Technology, Mickiewicza \\ 30, 30-059 Krakow, Poland
}

\begin{abstract}
Arsenic is one of the most toxic elements on Earth and causal factor of serious poisonings and diseases. Agency for Toxic Substance and Disease Registry placed this metaloid on the $1^{\text {st }}$ place of Substance Priority List. The explanation of mechanisms of As migration from environment to organisms is crucial step on a way to limit poisonings caused by this element. This review presents the most actual knowledge about As transporters involved in migration and distribution of As from the environment via food chain into human body, focusing on molecular cell transporters of arsenic. The mechanism of translocation depends on the As form. Three allotropes and nine states of oxidation either organic $\mathrm{As}\left(\mathrm{As}_{\mathrm{org}}\right)$ and inorganic $\mathrm{As}\left(\mathrm{As}_{\mathrm{in}}\right)$ were identified. In biochemical aspect the most significant are $\mathrm{As}(\mathrm{III})$ and $\mathrm{As}(\mathrm{V})$ forms. Pit and Pst are transporters responsible for $\mathrm{As}(\mathrm{V})$ intake in every organism regarding $\mathrm{As}(\mathrm{V})$ form similarity to phosphate compounds. In plants, e.g. domesticated Oryza sativa different specialized transmembrane PHT proteins like OsPht1;1 and OsPht1;8 and their homologues uptake and distribute As(V) compounds within plant. As $s_{\text {in }}$ (III) migration pathway leads via aquaglyceroporins such like GlpF in E. coli, NIPs members (e.g. AtNip, OsNip, OsPIP) in plants or AQPs in mammalian cells. In dependence on type of organism aquaglyceroporins are transporters involved in uptake as well as efflux of As(III) from the cell. Therefore, organisms can contribute to increase of more toxic As form in environment. Another pathways for As(III) uptake are hexose permeases identified in yeast and mammalian cells. Organic arsenic compounds intake was studied mainly on As methylated derivatives and it was shown that is processed via aquaglyceroporins like $\mathrm{As}_{\mathrm{in}}(\mathrm{III})$ forms, although molecular mechanism of $\mathrm{As}_{\text {org }}(\mathrm{III})$ and $\mathrm{As}_{\text {org }}(\mathrm{V})$ seems to be different.
\end{abstract}

\begin{abstract}
Abbreviations and symbols: APL: Acute Promyelocytic Leukemia; AQP: Aquaporin; $\mathrm{As}_{\text {in: }}$ Inorganic Arsenic Compounds; $\mathrm{As}_{\text {org: }}$ Organic Arsenic Compounds; ATSDR: Agency For Toxic Substance And Disease Registry; DMA ${ }^{\mathrm{III}}$ : Dimethylated Derivatives of As(III); DMA ${ }^{\mathrm{V}}$ : Dimethylarsinic Acid; EPA: Environmental Protection Agency; ER: Endoplasmic Reticulum; GLUT1: Glucose Transporter 1; Mas(III): Methylated As(III); MIP: Major Intrinsic Proteins; MMA ${ }^{\mathrm{III}}$ : Monomethylated Derivatives of As(III); MMAv ${ }^{\mathrm{v}}$ : Monomethylarsonic Acid; NIP: Nodulin 26-Like Intrinsic Proteins; PHS: Phosphate H+ Symporter; PHT: Phosphate Transporter; $\mathrm{P}_{i}$ : Inorganic Phosphate; PIP: Plasma Membrane Intrinsic Proteins; Pit: Low-Affinity Inorganic Phosphate Transporter; Pst: Inorganic Phosphate-Specific Transporter; TIP: Tonoplast Intrinsic Proteins; TMA ${ }^{\text {III }}$ : Trimethylated Derivatives of As(III); $\mathrm{TMAO}^{\mathrm{v}}$ : Trimethylarsine Oxide; WHO: World Health Organisation
\end{abstract}

\section{Introduction}

Arsenic - a representative of metaloids group - is one of the most toxic elements on Earth (Ghosh, et al., 2008). It is causal factor of different types of cancer, nervous and peripheral vascular system diseases, neurological disorders and diabetes [1-3]. What is more, As demonstrates teratogenic activity, causing low birth weight and fetal loss, as well as delays of infant mental and physiological development [4]. As limits the uptake of important microelements, such as iron or zinc [5,6]. Considering As toxicity, Agency for Toxic Substance and Disease Registry (ATSDR) placed this metaloid on the very top of Substance Priority List (http://www.atsdr.cdc.gov/spl/) [7]. Despite of the toxic properties, As is still applied as a chemotherapeutic agent in several diseases therapy, but in $18^{\text {th }}$ and $19^{\text {th }}$ centuries it was basis of pharmacology of that time. Nowadays, drugs with As are used in therapy of acute promyelocytic leukemia (APL) (e.g. Trisenox) or diseases caused by protozoan parasites $[8,9]$. In nature As forms three allotropes [10] and nine states of oxidation, from -III to V depending on type of chemical bonds. In terms of biochemical aspects, the most significant are $\mathrm{As}(\mathrm{III})$ and $\mathrm{As}(\mathrm{V})$ compounds [11-13]. Under reducing conditions, such as flooded rice paddy fields, As(III) dominates $\mathrm{As}(\mathrm{V})$. On the other hand, As(V), the oxidized form, dominates As(III) under oxidative conditions. As is involved in forming about 200 minerals, out of which the most commonly spread are arsenopyrite, loellingite or realgar.

Arsenic content in upper layers of Earth crust is small and according to recent analyses reaches $2 \mathrm{ppm}$ on average. As a consequence of weathering processes As infiltrates to soils, waters and the air, but the major amount of this element is a result of anthropogenic activity, mainly mining and metallurgy industry, usage of pesticides and wood

Correspondence to: Dariusz Latowski, Department of Plant Physiology and Biochemistry, Faculty of Biotechnology, Biochemistry and Biophysics, Jagiellonian University, Gronostajowa 7, 30-387, Krakow, Poland, Tel: (+48) 12 66460 02; Fax: (+48) 1266469 02; E-mail: dariuszlatowski@gmail.com

Key words: arsenic uptake, aquaporins, permeases, phosphate transporters, rice

Received: August 27, 2016; Accepted: September 22, 2016; Published: September 26, 2016 
preservatives or semiconductors [7,14] Apart from mineral compounds As forms also organic arsenic $\left(\mathrm{As}_{\mathrm{org}}\right.$ ) compounds [7], several of them are produced as ingredients of pesticides. The most widely spread in the environment $\mathrm{As}_{\text {org }}(\mathrm{V})$ compounds are monomethylarsonic acid $\left(\mathrm{MMA}^{\mathrm{v}}\right)$, dimethylarsinic acid $\left(\mathrm{DMA}^{\mathrm{v}}\right)$ and trimethylarsine oxide $\left(\mathrm{TMAO}^{\mathrm{V}}\right)$. Comparing to inorganic $A s\left(\mathrm{As}_{\mathrm{in}}\right)$ compounds, the concentration of organic forms is low [15], moreover the concentration of mono-, di-, and trimethylated derivatives of $\mathrm{As}(\mathrm{III})\left(\mathrm{MMA}^{\mathrm{III}}, \mathrm{DMA}^{\mathrm{III}}\right.$, $\mathrm{TMA}^{\mathrm{III}}$ ) is even lower because of high volatility they present [16]. Organic As compounds can be also created by organisms as an effect of biotransformation of $\mathrm{As}_{\text {in }}$ [17]. Transformation of $\mathrm{As}_{\text {in }}$ into methyl derivatives is common metabolic reaction of mammals. Methylated forms of As(III) are considered to be more toxic than $\mathrm{As}_{\text {in }}$ (III), on the other hand $\mathrm{As}_{\text {in }}$ (III) forms are about 60 times more toxic than $\mathrm{As}_{\text {in }}(\mathrm{V})$ compounds. On the other hand, the toxicity of $\mathrm{As}_{\mathrm{in}}(\mathrm{V})$ is about 70 times higher in comparison with two common $\mathrm{As}_{\text {org }}$ forms, i.e., $\mathrm{MMA}^{\mathrm{V}}$ and $\mathrm{DMA}^{\mathrm{v}}$, which are characterized by moderate toxicity level [18, 19]. $\mathrm{MMA}^{\mathrm{V}}$ and $\mathrm{DMA}^{\mathrm{V}}$ in mammalian organisms are excreted with urine and feaces as products of $\mathrm{TMA}^{\mathrm{III}}$ oxidative biotransformation [7]. According to Environmental Protection Agency (EPA) the most common reason of poisoning with As is consumption of water and foods contaminated with this element [7]. It was estimated that about as many as 40 million people in the world are exposed to consumption of water contaminated with As (Nordstrom, 2002). It was the reason why World Health Organization (WHO) lowered allowable content of As in waters from $50 \mu \mathrm{gAs} / \mathrm{l}$ to $10 \mu \mathrm{gAs} / \mathrm{l}$, but in several countries, such like Bangladesh, India, Vietnam, Thailand or Taiwan the contamination of waters by As is significantly higher. Analyzed drinking water samples from West Bengal contained As of concentration reaching level up to $1000 \mu \mathrm{g} / \mathrm{l}$, whereas the highest concentration was detected in Ramnagar village and reached $3700 \mu \mathrm{g} / \mathrm{l}[20,21]$.

Among food products the most contaminated with As is rice, which intakes from soil higher amounts of As in comparison with other domesticated plants $[22,23]$. Results of some research show, that people consuming rice of amounts higher than average, have even $40 \%$ higher As content in organism than another. Significant concentrations of As were also detected in Brussel's sprout [24]. High concentrations of $\mathrm{As}_{\text {in }}$ was confirmed in research on hijiki brown algae (Hizikia fusiformis), called brown sea vegetable in Japan, Korea and China. According to Japanese folklore, regular consumption of small amounts of hijiki aids health and beauty, including lustrous, thick, black hair. It was also adopted to culinary applying in United Kingdom and North America. Recently it has been shown that it contains potentially toxic quantities of $\mathrm{As}_{\mathrm{in}}$, and consumption of hijiki have been discouraged by the food safety agencies of several countries, such as Canada, the United Kingdom and the United States but not in Japan [25] 2014: Survey of Total and Inorganic Arsenic in Seaweed - Food Safety Research Information Office". United States Department of Agriculture. 2004. Retrieved 30 September 2014; Anon., 2015: Inorganic Arsenic and Hijiki Seaweed Consumption. Canadian Food Inspection Agency. 20 March 2012. Retrieved 12 March 2015).

The source of As are also sea fish as well, such as tuna, mackerel, salmon or sardines, but fortunately the As in their tissues is incorporated in less toxic $\mathrm{As}_{\text {org }}$ compounds such as arsenobetaine and arsenocholine which are easily removed from human organism. Despite of this, it was proved that in the case of people consuming mentioned fish species once a week, the concentration of As in the body was 7\% higher than in the case of those who consume once a month or less frequently [24]. In general sea organism's bodies contain more As than fresh water ones, which is explained by the effect of water salinity on ability of As accumulation $[26,27]$. The ingestion of As consumed with water or food from gastrointestinal tract depends mainly on the solubility and can reach up to $95 \%$ [28]. Organisms are exposed mainly to As in the form of arsenates(V) $\left(\mathrm{HAsO}_{4}^{2-}, \mathrm{H}_{2} \mathrm{AsO}_{4}^{-}\right)$and arsenates(III) (arsenines) $\left(\mathrm{As}(\mathrm{OH})_{3}, \mathrm{H}_{2} \mathrm{AsO}_{3}^{-}\right)$. Both forms are transported in random way, as the same mechanism is used for transport of another compounds which are indispensable for metabolism [29]. Thus, arsenates(V) are taken up via phosphate transporters [30,31]. Whereas arsenates(III) via aquaglyceroporins transporting e.g. water and glycerin [3234]. Arsenates(III), which under physiological $\mathrm{pH}$ conditions are not ionized, migrate inside to cells faster than negatively charged arsenates(V) [35,36]. As(III) transporters characterizes two-way transport, what is used particularly by microorganisms taking up $\mathrm{As}(\mathrm{V})$ and reducing to As(III) to remove this form out of the cell. The process of reduction $\mathrm{As}(\mathrm{V})$ to $\mathrm{As}(\mathrm{III})$ is typically frequent in habitats under oxygen deficiency conditions [7]. The explanation of As intake mechanisms from environment and distribution of its compounds through the food chain and within human body would be important information for protection and therapy of poisoning with this element. This review deals with that topic focusing on the most actual knowledge about arsenic transporters involved in migration and distribution of As from the environment via food chain into human body.

\section{Biochemical pathways of arsenic $(V)$ influx}

\section{Pit and Pts transport arsenic(V) in bacteria}

Regarding structural similarities, the mechanism of arsenates $(\mathrm{V})$ intake in every living organism is the same and is conducted via phosphate transporters (Figure 1). Some of them present high affinity to inorganic phosphate $\left(\mathrm{P}_{\mathrm{i}}\right)$, whereas another one is low. In $70^{\prime}$ research on Escherichia coli resulted with discovering of two phosphate channels, which don't distinguish $\mathrm{P}_{\mathrm{i}}$ from arsenate $(\mathrm{V})$. One of them is Pit, a low-affinity, high capacity constitutive system playing crucial role in process of $\mathrm{As}(\mathrm{V})$ intake. Cells dependent upon the Pit system have a $\mathrm{K}_{\mathrm{M}}$ of $38.2 \pm 0.4 \mu \mathrm{M}$ and $\mathrm{a} \mathrm{V}_{\max }$ of $55 \pm 1.9 \mathrm{nmol}$ of $\mathrm{P}_{\mathrm{i}}$ (mg [dry weight $\left.]^{-1} \mathrm{~min}^{-1}\right)$, and cannot grow in the presence of an $A s(V)$ to $P_{i}$ ratio of 10 in the medium $[30,37,38]$. The second transporter is high-affinity but low-capacity system induced by phosphate starvation, named Pst [39]. It transports As(V) into cells less efficiently than Pit. $K_{M}$ of cells dependent upon Pst system have nearly 90 times higher P. affinity (K.

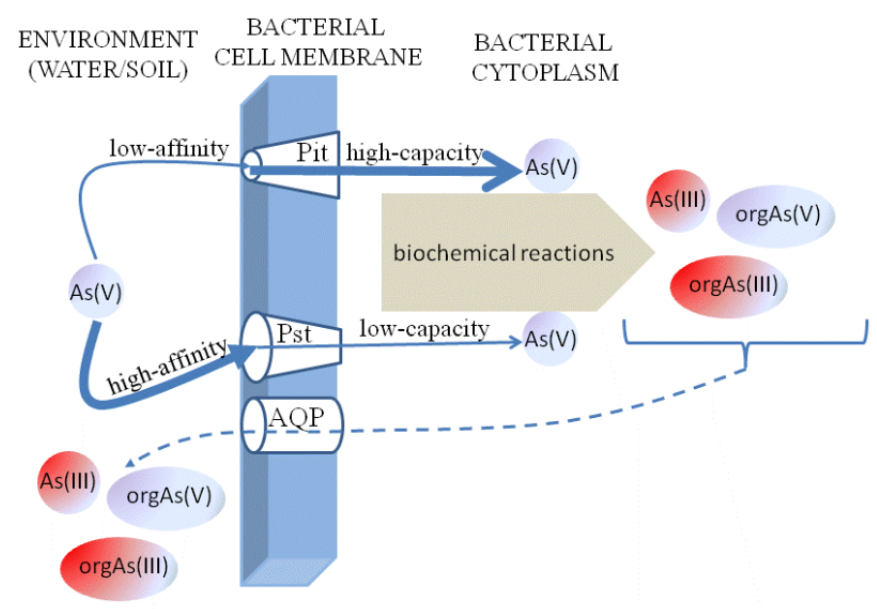

Figure 1. The share of the best-known bacterial As $(\mathrm{V})$ transporters in As uptake. Pit - low affinity, high capacity phosphate transporter; Pst - high affinity, low capacity phosphate transporter; $\mathrm{AQP}$ - aquaporins 
of Pst is $0.43 \pm 0.2 \mu \mathrm{M} \mathrm{P}_{\mathrm{i}}$ ) than cells with Pit system. However, they uptake $\mathrm{P}_{\mathrm{i}}$ with $\mathrm{V}_{\max }$ more than 3 times lower $\left(15.9 \pm 0.3 \mathrm{nmol}\right.$ of $\mathrm{P}_{\mathrm{i}}$ (mg [dry weight $]^{-1} \mathrm{~min}^{-1}$ ) than cells dependent upon the Pit system. Additionally, the cells dependent upon Pst system can easily grown in the presence of arsenate in the environment and probably it is the only one $\mathrm{P}_{\mathrm{i}}$ transporter synthesized by bacteria constantly exposed to $\mathrm{As}(\mathrm{V})$ in environment [38]. It is claimed, that the lack of Pit expression is the protective mechanism limiting non-specific $\mathrm{As}(\mathrm{V})$ ingestion into the cells [40].

\section{Members of Pht1 family are guilty of introducing arsenic(V) into the trophic chain}

In the case of plants there is a specified group of incorporated in plasma membrane phosphate transporters which presents high affinity to phosphate $(\mathrm{V})$, called $\mathrm{P}_{\mathrm{i}}$ transporter 1 (Pht1; TC 2.A.1.9, the PHS family) (Figure 2). The characteristic property of this protein family is presence of 12 membrane spanning domains [41]. Results of the research have shown, that in the case of Arabidopsis thaliana possessing nine proteins Pht1 (PHT1 proteins), six of them are involved in processes of uptake and transport of $\mathrm{As}_{\text {in }}(\mathrm{V})(\mathrm{AtPht} 1 ; 1,4$, $5,7,8,9)$ (Figure 2). Eight out of those nine proteins are synthesized in roots under condition of $\mathrm{P}_{\mathrm{i}}$ deficiency $[41,42,43]$. First identified AtPht1;1 and AtPht1;4 are involved in uptake of $\mathrm{P}_{\mathrm{i}}$ and arsenates $(\mathrm{V})$ from soil in presence of high, as well as low phosphorus content [44]. AtPht 1;5 supports translocation of $\mathrm{As}_{\text {in }}(\mathrm{V})$ and $\mathrm{P}_{\mathrm{i}}$ from older leaves to sink (young leaves, growing roots and developing seeds) organs (Figure 2) $[41,23]$. It was also observed that deficiency of $P_{i}$ induces expression of AtPht1;5, especially in the flowers, cotyledons and phloem cells of older leaves [43]. Also AtPht1;7 specifically expressed in reproductive tissues of Arabidopsis participates in $\mathrm{As}_{\text {in }}(\mathrm{V})$ influx. AtPht1;8 and 9, which dominate in Arabidopsis roots, under conditions of phosphorus deficiency contribute to $\mathrm{As}_{\text {in }}(\mathrm{V})$ uptake from soil [45]. Recently several transcription factors of $A$. thaliana were identified and they are involved in control of $\mathrm{As}_{\text {in }}(\mathrm{V})$ intake by regulation of $A t P h t 1$ genes expression AtPht1 [46,47]. What is more, in the endoplasmic reticulum (ER) of A. thaliana there was AtPhf1 ( $\mathrm{P}_{\mathrm{i}}$ Transporter Traffic Facilitator 1) identified. This protein inhibits AtPht1;1 transport from ER to the plasma membrane, by this way limiting the number of AtPht $1 ; 1$ and as a consequence the uptake of $\mathrm{As}_{\mathrm{in}}(\mathrm{V})[48]$.

AtPht1 show from $60 \%$ to $95 \%$ similarity of sequence in comparison to its homologues identified in such plants like rice (Oryza

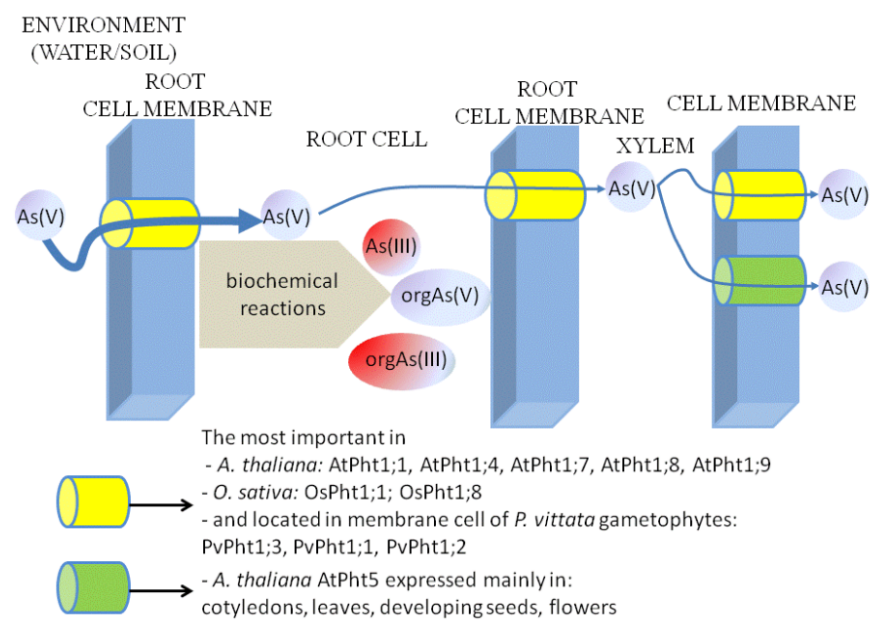

Figure 2. The most accurately researched plant $\mathrm{As}_{\text {in }}(\mathrm{V})$ transporters. sativa), wheat (Triticum aestivum), potato (Solanum tuberosum), tomato (Solanum lycopersicum), tobacco (Nicotiana tabacum) or Pteris vittata known from its arsenic hyper-accumulation abilities [49-51]. What is more, in case of many monocots and dicots species, and both As-hyper accumulators and non- hyper accumulators it was proved, that $\mathrm{As}_{\text {in }}(\mathrm{V})$ competes $\mathrm{P}_{\mathrm{i}}$ while ingestion process into cell via phosphate transporters of high as well as low affninity to $P_{i}[15,52-58]$. This fact indicates on common contribution of plant Pht1 proteins not only in $\mathrm{P}_{\mathrm{i}}$ transport, but also in uptake of $\mathrm{As}_{\mathrm{in}}(\mathrm{V})$ and its distribution in plant [23]. The promoting effect of As on plants growth in the presence of its small concentrations is a result of $\mathrm{P}_{\mathrm{i}}$ intake stimulation by As [56].

In plant biochemistry and genetics studies A. thaliana is a model organism, but it cannot be applied directly for practical, significant for human organism pathways analysis of As translocation from the environment to the human cells. In contrast to A. thaliana, rice $(O$. sativa) is a domesticated plant significant for nutrition. O. sativa is able to accumulate As and additionally is often grown on areas contaminated with this element. Two of twelve identified in rice $\mathrm{P}_{\mathrm{i}}$ transporters, i.e. OsPht1;1 and OsPht1;8 are involved in processes of uptake and translocation of $\mathrm{As}_{\text {in }}(\mathrm{V})$ in plant (Figure 2). Both OsPht 1;1 and $O s P h t 1 ; 8$ are expressed independently on concentration of phosphorus. Transport OsPht1;1 from ER to the plasma membrane depends on OsPhf1 responsible for synthesis of protein with function similar to AtPhf1 in A. thaliana. Transcription factor regulating expression of $O s P h t 1 ; 8$ called OsPhr2 ( $\mathrm{P}_{\mathrm{i}}$ starvation response 2$)$ was also identified [23,59-62]. Recent research resulted with identification of three Pht1 transporters of Pteris vittata (PvPht1) (Figure 2). By using transgenic yeast cells and radiolabeling with 32P it was observed that $\mathrm{PvPht} 1 ; 3$ demonstrates the same affinity to $\mathrm{P}_{\mathrm{i}}$ as AtPht1;5, but its affinity to $\mathrm{As}_{\mathrm{in}}(\mathrm{V})$ is significantly higher. Moreover, yeast cells with PvPht 1;3 were able to accumulate more $\mathrm{As}_{\text {in }}(\mathrm{V})$ than with AtPht $1 ; 5$.

Pht1 transporters does not participate only in uptake $\mathrm{As}_{\text {in }}(\mathrm{V})$ from environment, but are also involved in its direction to xylem vessels and then can be distributed between cells or even from one cell compartment to another as well [60,63-65]. As an example can be given $\mathrm{As}_{\text {in }}(\mathrm{V})$ which is co-substrate for three mitochondrial proteins localized to the inner-mitochondrial membrane and responsible for dicarboxylate exchange with co-substrates such as $\mathrm{P}_{\mathrm{i}}$, between the mitochondrial matrix and the cytosol [66]. However, it should be regarded, that in case of non-hyperaccumulators only about $3 \%$ of As ingested by roots is translocated into stem [67]. It was demonstrated, that in A. thaliana leaves even $97 \%-100 \%$ of As exists in form of As on III state of oxidation [68] similarly like in the roots and shoots of Brassica juncea (96-100\%) [69] or roots of tomato and rice (92-99\%) [70]. Those examples prove very efficient and fast reduction of ingested $\mathrm{As}_{\text {in }}(\mathrm{V})$ compounds. An interesting phenomenon is the process of widely spread, efficient and quick reduction of $\mathrm{As}_{\text {in }}(\mathrm{V})$ within all groups of organisms, starting from bacteria to the final biotransformations of As in human body [71]. Additionally, arsenates(V) compete with $\mathrm{P}_{\mathrm{i}}$ during translocation into cell because of the structural analogy [56,57], what is the reason why increase of $\mathrm{P}_{\mathrm{i}}$ concetration limits the $\mathrm{As}_{\mathrm{in}}(\mathrm{V})$ intake and inversely - deficiencies of $\mathrm{P}_{\mathrm{i}}$ enhance the uptake of $\mathrm{As}_{\text {in }}(\mathrm{V})$.

\section{Biochemical pathways of $\mathrm{As}_{\text {in }}$ (III) influx}

The mechanism of uptake $\mathrm{As}_{\mathrm{in}}(\mathrm{V})$ via phosphate transporters was well studied, however the pathway of $\mathrm{As}_{\text {in }}$ (III) transport into cell was explained only in 2004. [72] discovered that E. coli protein GlpF responsible for antimony(III) uptake [32] is involved in transport of $\mathrm{As}_{\mathrm{in}}$ (III) into cell as well (Figure 3). GlpF protein is the first identified 


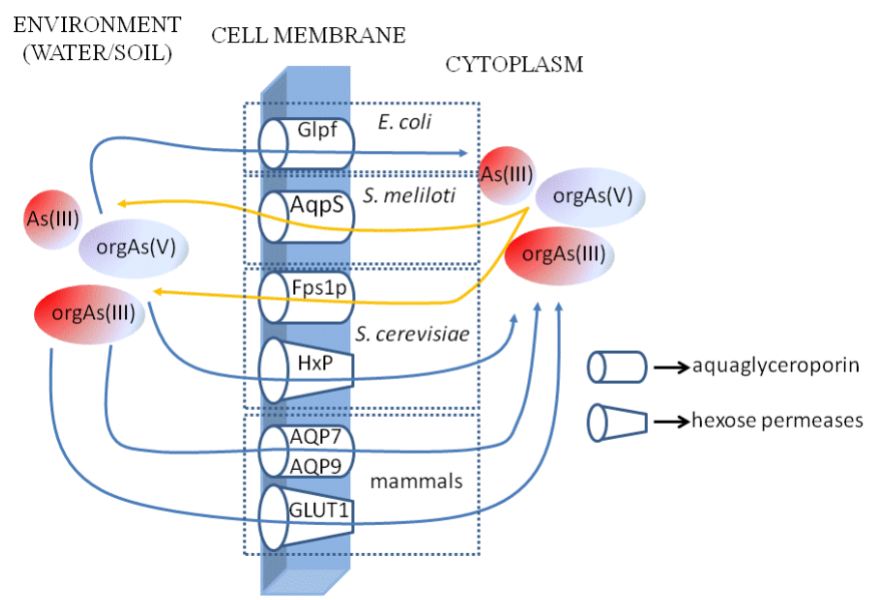

Figure 3. The most accurately researched $\mathrm{As}_{\mathrm{in}}$ (III) and $\mathrm{As}_{\text {org }}$ transporters of bacteria, yeast and mammals.

representative of aquaporin's known also as major intrinsic membrane proteins (MIP) [74]. Aquaporin's family is divided into two groups: true aquaporin's which are water channels, and aquaglyceroporins which GlpF belongs to, with larger pore channels but low to no water permeability. Aquaglyceroporins facilitate transport of non-charged particles, such like glycerol, urea, ammonia or boric and silicic acid [75-78]. Several studies demonstrated also that aquaglyceroporins of E. coli (GlpF), yeast (Fpslp) and mammals (mouse AQP7, rat and human AQP9) are able to transport As in $_{\text {in }}$ (III) (Figure 3) [71]. Whereas E. coli GlpF transports $\mathrm{As}_{\text {in }}$ (III) form environment into cell, the GlpF orthologue, AqpS of the legume symbiont Sinorhizobium meliloti is responsible for $\mathrm{As}_{\text {in }}$ (III) efflux [79]. Similarly, to many other bacterial or yeast species, $S$. meliloti uptakes $\operatorname{As}_{\text {in }}(\mathrm{V})$ compounds, reduces in enzymatic pathway to As(III) form and finally remove this product from the cell to environment [71,80] (Figure 3). Yeast cells also influx $\mathrm{As}_{\text {in }}(\mathrm{V})$ via phosphate ion channels and subsequently reduce it to $\mathrm{As}(\mathrm{III})$ and then removed with aquaglyceroporin Fpslp which is an orthologue of E. coli. Although AqpS as well as Fps1p are both the GlpF orthologues they transport $\mathrm{As}_{\text {in }}$ (III) in reverse to GlpF direction (Figure 3). The examples given above allow to conclude, that depending on type of organism, aquaglyceroporins are transporters involved either in $\mathrm{As}_{\text {in }}$ (III) uptake or $\mathrm{As}_{\text {in }}$ (III) efflux by the cells (Figure 3). Plants also have aquaglyceroporins, which make them significant link of food chain intermediating efficiently in migration of As from the environment to animal and human organism.

\section{Aquaglyceroporins are broad gates for $\mathrm{As}_{\text {in }}$ (III) uptake from environment to the cells}

Plant aquaporins are the most researched $\mathrm{As}_{\text {in }}$ (III) transporters facilitating efficient transport of these compounds from environment into cell. They are classified as representatives of nodulin 26-like intrinsic protein (NIP; TC 1.A.8, the MIP family) family [76-78,81]. NIPs are one of the four plant aquaporins subfamilies. The another three groups are: plasma membrane intrinsic proteins (PIPs), tonoplast intrinsic proteins (TIPs) and small basic intrinsic proteins (SIPs) $[82,83]$. It is believed that plants obtained NIPs genes as a result of horizontal gene transfer from bacteria [75].

Six of nine identified A. thaliana NIPs (AtNip) participate in $\mathrm{As}_{\text {in }}$ (III) transport, similarly to the O. sativa, where six of ten identified OsNip proteins have this function towards $\mathrm{As}_{\text {in }}$ (III). It was proved, that two Nip proteins of Lotus japonica and one of Hordeum vulgare are able to translocate $\mathrm{As}_{\text {in }}$ (III). The most important for $\mathrm{As}_{\text {in }}$ (III) uptake from environment to the root AtNips are AtNip1;1, AtNip3;1, AtNip5;1 and AtNip6;1. Additionally, AtNip5;1 and AtNip6;1 are involved in transmembrane $\mathrm{As}_{\text {in }}$ (III) transport and AtNip3;1 facilitates $A s_{\text {in }}$ (III) translocation from the root to the stem (Figure 4). AtNip7;1 is selectively expressed in anthers and pollen tissues and gene encoding AtNip $1 ; 2$ is strongly expressed in seeds $[23,76,77,84,85]$. In O. sativa OsNip2;1 is responsible for $\mathrm{As}_{\text {in }}$ (III) uptake from the environment into root, whereas OsNip3;2 is expressed primarily in anthers and suspension cells (Figure 4). OsNip2;1 participates in $\mathrm{As}_{\text {in }}$ (III) uptake, but together with OsNip3;2 facilitates migration of this form through cellular membranes, having contribution to distribution of As throughout plant organs. Both studied Nips representatives of $L$. japonicus, i.e. LjNip5;1 and LjNip6;1 and HvNIP1;2 of H. vulgare are also involved in transport of $\mathrm{As}_{\text {in }}$ (III) through cellular membranes (Figure 4) [23].

If consider the plant transfer of As from the environment to animal and human cells, the most significant role plays rice $(O$. sativa) consumption [86]. It is cultivated in soil of low aeration level, where $\mathrm{As}_{\mathrm{in}}$ (III) dominates another forms. The rice contaminated with As, besides water, is factor causing serious poisonings. By aquaglyceroporins rice easily and efficiently absorb $\mathrm{As}_{\text {in }}$ (III) from the soil and water and accumulate in seeds [22]. The concentrations of As in grain reach the level which can endanger health of people for whom rice is the base of diet [86]. OsNip2;1 is the example of aquaglyceroporin which is major rice $\mathrm{As}_{\text {in }}$ (III) transporter, but it is also called silicon ( $\mathrm{Si}$ ) influx transporter (OsLsi1) as its function is uptake of $\mathrm{Si}$ from environment. The diameter of silicic acid molecule (4.38 $\AA$ ) is close similar to diameter of tetrahedron of $\left[\mathrm{As}(\mathrm{OH})_{3}\right](4.11 \AA)$ which dominates form of arsenite at $\mathrm{pH}$ below value of its $\mathrm{pK}_{\mathrm{a}}$ of 9.2. Under physiological conditions arsenite forms non-charged arsenous acid particles and OsNip2;1 (OsLsi1) channel also remains electrically neutral, what facilitates transport of this As compound [78].

The another silicic transporter, OsLsi6 (OsNip2;2), belongs to OsNip - subfamily, similarly to OsNip1;1 and OsNip3;1 is characterized by low level of expression and it is suggested, that does not possess significant function in process of uptake $\mathrm{As}_{\mathrm{in}}$ (III) from the environment $[23,78]$. Studies on recently identified transporter OsNip3;3 demonstrated that it uptakes $\mathrm{As}_{\text {in }}$ (III) from the environment

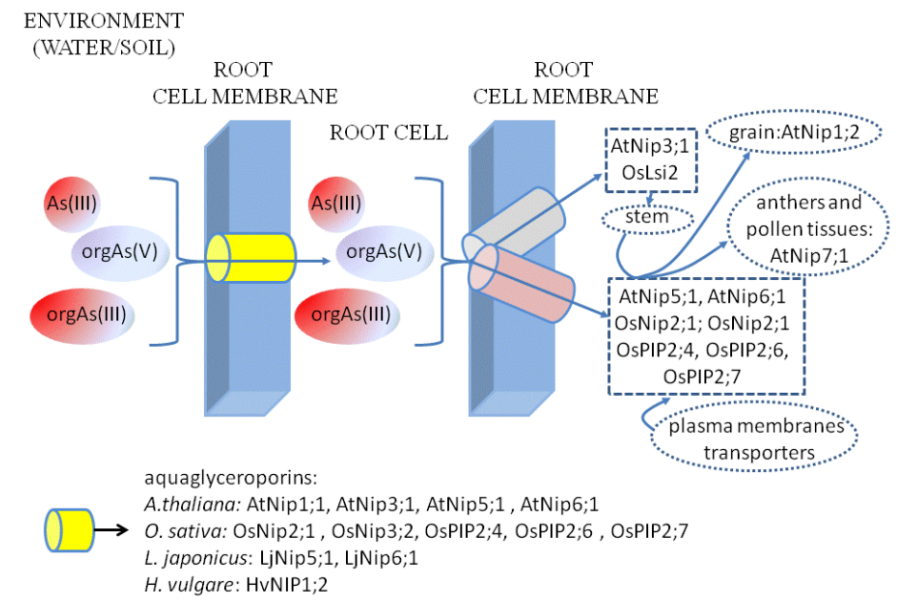

Figure 4. Simplified scheme of occurrence and functions of identified plant $\mathrm{As}_{\mathrm{in}}$ (III) and $\mathrm{As}_{\text {org }}$ transporters. 
and does not require the presence of $\mathrm{As}_{\text {in }}$ (III) to be synthetized, but more precise research is required $[23,87,88]$. Whereas OsNip $2 ; 1$ (OsLsi1) located in the distal side of epidermal and endodermal membrane cells of rice root, transport $\mathrm{As}_{\text {in }}$ (III) from the environment, the another silicic transporter OsLsi2 located in the membranes on the proximal side of the same cells is responsible for transport of $\mathrm{As}_{\text {in }}$ (III) from root cells to xylem (Figure 4). By this OsLsi2 contributes to distribution of As in rice and as a consequence to accumulation of $\mathrm{As}_{\text {in }}$ (III) in rice grain. Thus, OsLsi2 transporter is the main factor enhancing accumulation of $\mathrm{As}_{\text {in }}$ (III) in rice grain, and by this toxic effect of contaminated with As rice on health of millions people on the world $[78,89,90]$. The expression of this protein in rice is not high, but independent on the presence of arsenic in the environment. The increase of $\mathrm{Si}$ concentration in soil inhibits accumulation of $\mathrm{As}_{\text {in }}$ (III) [78] and application of sulfur fertilizers counteracts contamination of grain by decreasing $\mathrm{As}_{\mathrm{in}}(\mathrm{III})$ and $\mathrm{As}_{\mathrm{in}}(\mathrm{V})$ concentration in rice seeds as well $[91,92]$.

Another mechanism of As uptake limitation is forming the $\mathrm{Fe}$ plaques in rice and other plants growing on flooded areas (e.g. water species) rhizosphere $[93,94]$. Fe plaque consists of ferrihydrite, a widespread on the Earth's surface hydrous ferric oxyhydroxide mineral, and is formed on the root surface as a result of $\mathrm{Fe}^{2+}$ to $\mathrm{Fe}^{3+}$ oxidation by the oxygen released through aerenchyma of the roots of the plants growing in anaerobic soils.

Oxidized iron strongly adsorbs to arsenate. It was shown, that the concentrations of $A s_{\text {in }}(\mathrm{V})$ within iron plaques of rice roots were 5 times higher than in root tissues of rice. Iron plaques on the roots of tested plants contain $70-80 \% \mathrm{As}_{\text {in }}(\mathrm{V})$ and $20-30 \% \mathrm{As}_{\text {in }}$ (III). Thus, the iron plaque formed on roots surface is natural barrier protecting from migration of As to the plant. Results of short-term experiments on As uptake by excised rice roots demonstrated, that whereas iron plaques limit $\mathrm{As}_{\text {in }}(\mathrm{V})$ uptake, on the other hand increase this process in case of $\mathrm{As}_{\text {in }}$ (III) $[93,95-99]$ It was supposed, that this relation is associated with $\mathrm{As}_{\text {in }}$ (III) transporters efficiently operating within rice cell membranes. These transporters shift the balance of $\mathrm{As}_{\text {in }}$ (III) binding reaction to the form not associated with iron plaques but quickly ingested by the roots of rice.

Apart from members of the NIPs family there were identified three other aquaporins belonging to the rice plasma membrane intrinisic proteins in rice (PIP TC 1.A.8, MIP family) marked: OsPIP2;4, OsPIP2;6 and OsPIP2;7. These proteins are involved in transport of $\mathrm{As}_{\mathrm{in}}$ (III) in the root and stem of rice and in contrast to the family of aquaporins Nip their synthesis is strongly down-regulated in response to $\mathrm{As}_{\text {in }}$ (III) [100].

The process of uptake and transport of $\mathrm{As}_{\text {in }}$ (III) was well studied for mammals, which use aquaglyceroporins similarly to other groups of organisms. At least for 13 aquaporines indentified in mammals $\mathrm{As}_{\text {in }}$ (III) uptake was documented for AQP7 translocating As (III) the most efficiently, and for AQP9 (Figure 3), which transports $\mathrm{As}_{\text {in }}$ (III) better than hAQP7. Among other researched aquaporins only two, i.e., hAQP3 i hAQP10 demonstrated ability of As in (III) uptake, but of not significant amounts and the study results have been not equivocal [98].

\section{$\mathrm{As}_{\text {in }}$ (III) inlux by gatesother than aquaglyceroporins}

Apart from aquaglyceroporins there were identified another types of proteins responsible for As (III) uptake. In yeast cells the major $\mathrm{As}_{\text {in }}$ (III) influx transporters are transmembrane hexose permeases [101] (Figure 3). In plants, proteins with strong homology to the yeast hexose permeases are present, however it is still unexplored if they are involved in $\mathrm{As}_{\mathrm{in}}$ (III) migration to the plant cells. In contrast to plants, in mammalian cells additional to aquaglyceroporins $\mathrm{As}_{\text {in }}$ (III), transporter of glucose 1 (GLUT1) was identified (Figure 3). GLUT1 is the homologue of yeast hexose permease and is the most explored and ubiquitous isoform of GLUT family. Under physiological conditions high expression of GLUT1 is observed in erythrocytes (3-5\% of total transmembrane proteins), endothelium and epithelium, blood-brain barrier, eye, placenta and mammary gland [102]. GLUT1 is responsible for transport of glucose and 2-deoxyglucose, but also galactose, mannose, glucosamine and ascorbic acid [102,103]. Results of comparable analyses of $\mathrm{As}_{\text {in }}$ (III) transport ability by GLUT1 and yeast permeases Hxtlp, Hxt3p, Hxt4p, Hxt5p, Hxt7p, Hxt9p and Hxt10p demonstrated, that GLUT1 is the least efficient $\mathrm{As}_{\text {in }}$ (III) transporter. However, when the efficiency of methylarsenous(III) acid (MAs(III)) transport was tested, GLUT1 activity occurred to be the most efficient [104].

\section{Biochemical mechanisms of organoarsenic compounds influx}

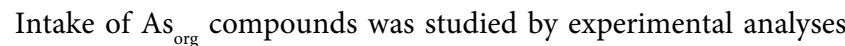
of its methylated derivatives. It is believed that these forms migrate into cell via aquaglyceroporins (Figure 3 ), the same pathways like $\mathrm{As}_{\text {in }}$ (III) and independently on their oxidation states, although it was demonstrated that Fps1p identified in yeasts was unable to transport MAs(III) [105]. Yeast cells influx MAs(III) by their hexose permeases, however rate of the MAs(III) uptake by this way is slower than for $\mathrm{As}_{\text {in }}$ (III) forms [104]. In case of the E. coli, the same transport rate by GlpF was shown for MAs(III) and As in (III) [7,105].

Despite that in plants the high concentrations of methylated As have been detected, present knowledge about plant mechanisms of $\mathrm{As}_{\text {org }}$ compounds uptake still requires research. Previous studies have shown, that in rice the concentration of DMA is two times higher than As forms, although MMA ${ }^{\mathrm{III}}$ is influxed faster than $\mathrm{DMA}^{\mathrm{III}}[106,107]$. It is believed that rice roots are able to uptake organoarsenic compounds by the same transporters which are active for $\mathrm{As}_{\text {in }}$ (III), e.g. OsLsi1 (OsNip2;1) [108] (Figure 3). Similarly, to $\mathrm{As}_{\text {in }}$ (III), also uptake of methylated As by rice is inhibited with Si [109-111]. Another studies demonstrated, that uptake of $\mathrm{MMA}^{\mathrm{III}}$ and $\mathrm{DMA}^{\mathrm{III}}$ was decreased significantly in association with increase of glycerol concentration, what indicates on influx of mentioned $\mathrm{As}_{\mathrm{org}}$ forms by the pathways of glycerol [106]. The mechanism of organoarsenic compounds uptake in mammalian cells is similar to plants and E. coli and is processed by aquaglyceroporins. Additionally, it was observed that rat AQP9 is more efficient transporter of MAs(III) than of $\mathrm{As}_{\text {in }}$ (III) [7]. Apart from aquaglyceroporins also GLUT1 in mammal's cells is involved in transport of MAs(III). Analyzes of substrate specificity of GLUT1 expressed in Xenopus laevis oocytes demonstrated, that GLUT1 transports MAs(III) more effectively than yeast permeases, and the affinity of this common mammalian transporter to MAs(III) $\left(\mathrm{K}_{\mathrm{M}}\right.$ $\sim 1.2 \mathrm{mM})$ is more than two times higher than to glucose $(\mathrm{Km} \sim 3 \mathrm{mM})$ [112] and over four times higher than to 2-deoxyglucose (Km 5 mM) [113]. It was also concluded that inhibition of glucose uptake by GLUT1 caused by MAs(III) is not a competitive inhibition. MAs(III) binds to GLUT1 in another site than glucose. Additionally, both forskolin and cytochalsin B which are commonly known inhibitors of glucose transport, do not inhibit uptake MAs(III) by GLUT1 [104].

The pathways of uptake organic and inorganic As(III) forms seem to be the same (Figure 3), however if consider the mechanisms 
of $A s_{\text {org }}(\mathrm{V})$ and $A s_{\text {in }}(\mathrm{III})$ migration into cell, they are different $[7,114]$ demonstrated that $X$. laevis oocytes with human AQP9 cRNA showed enhanced uptake of both $\mathrm{MMA}^{\mathrm{v}}$ and $\mathrm{DMA}^{\mathrm{v}}$, however $\mathrm{Hg}(\mathrm{II})$ which is aquaporin inhibitor prevented influx of arsenicals through AQP9. On the other hand, while application of phloretin, an inhibitor of glycerol and water permeation via $A Q P 9$, it was observed that only $\mathrm{MMA}^{\mathrm{V}}$ and $\mathrm{DMA}^{\mathrm{v}}$ forms uptake was inhibited, in contrast to $\mathrm{As}_{\text {in }}$ (III) and MAs(III) [114]. The mechanism of this phenomenon remains unexplained as far.

Despite the progressing knowledge about the molecular mechanisms of various As compounds intake by different organisms cells, there are still many unexplained aspects related to migration of As from the environment to the food chain, and as a consequence human organism. Comprehensive research of those mechanisms will allow to limit the endangers and health complications caused by arsenic poisonings.

\section{Conflicts of interest}

The authors declare no conflict of interest.

\section{References}

1. Tseng CH, Tseng CP, Chiou HY, Hsueh YM, Chong CK, et al. (2002) Epidemiologic evidence of diabetogenic effect of arsenic. Toxicol Lett 133: 69-76. [Crossref]

2. Abernathy CO, Thomas DJ, Calderon RL. (2003) Health effects and risk assessment of arsenic. J Nutr 133(5 Suppl. 1): 1536S-1538S. [Crossref]

3. Tchounwou PB, Centeno JA, Patlolla AK (2004) Arsenic toxicity, mutagenesis, and carcinogenesis--a health risk assessment and management approach. Mol Cell Biochem 255: 47-55. [Crossref]

4. Tofail F, Vahter M, Hamadani JD, Nermell B, Huda SN, et al. (2009) Effect of arsenic exposure during pregnancy on infant development at 7 months in rural Matlab, Bangladesh. Environ Health Persp 117(2): 288-293. [Crossref]

5. Duan G, Liu W, Chen X, Hu Y, Zhu Y (2013) Association of arsenic with nutrient elements in rice plants. Metallomics 5: 784-792. [Crossref]

6. Brackhage C, Huang JH, Schaller J, Elzinga EJ, Dudel EG. (2014) Readily available phosphorous and nitrogen counteract for arsenic uptake and distribution in wheat (Triticum aestivum L.). Sci. Rep 4: 4944. [Crossref]

7. Yang HC, Fu HL, Lin YF, Rosen BP (2012) Pathways of arsenic uptake and efflux. Curr Top Membr 69: 325-358. [Crossref]

8. Carter NS, Fairlamb AH (1993) Arsenical-resistant trypanosomes lack an unusual adenosine transporter. Nature 361: 173-176. [Crossref]

9. Mead MN (2005) Arsenic: in search of an antidote to a global poison. Environ Health Perspect 113: A378-386. [Crossref]

10. Norman NC. 1998. Chemistry of Arsenic, Antimony and Bismuth. Springer. p. 50 ISBN 978-0-7514-0389-3

11. Kläning UK, Bielski BHJ, Sehested K. 1989. Arsenic(IV). A pulse-radiolysis study. Inorg Chem 28: 2717-2724.

12. Ellis BD, Macdonald CL (2004) Stabilized arsenic(i) iodide: a ready source of arsenic iodide fragments and a useful reagent for the generation of clusters. Inorg Chem 43: 5981-5986. [Crossref]

13. Janiak C, Meyer HJ, Gudat D, Alsfasser R. 2012. Moderne Anorganische Chemie, De Gruyter, Berlin/Boston, ISBN 978-3-11-024901-9, p.256

14. Ghosh P, Banerjee M, Giri AK, Ray K (2008) Toxicogenomics of arsenic: classical ideas and recent advances. Mutat Res $6 \quad$ 59: 293-301. [Crossref]

15. Abedin MJ, Feldmann J, Meharg AA. (2002) Uptake kinetics of arsenic species in rice plants. Plant Physiol 128: 1120-1128. [Crossref]

16. Mestrot A, Feldmann J, Krupp EM, Hossain MS, Roman-Ross G, et al. (2011) Field fluxes and speciation of arsines emanating from soils. Environ Sci Technol 45: 17981804. [Crossref]

17. Zhu YG, Rosen BP (2009) Perspectives for genetic engineering for the phytoremediation of arsenic-contaminated environments: from imagination to reality? Curr Opin Biotechnol 20: 220-224. [Crossref]
18. Akter KF, Owens G, Davey DE, Naidu R. (2005) Arsenic speciation and toxicity in biological systems. Rev Environ Contam T 184: 97-149. [Crossref]

19. rYamanaka K, Kato K, Mizoi M, An Y, Takabayashi F, et al. (2004) The role of active arsenic species produced by metabolic reduction of dimethylarsinic acid in genotoxicity and tumorigenesis. Toxicol Appl Pharmacol 198: 385-393. [Crossref]

20. Nordstrom DK (2002) Public health. Worldwide occurrences of arsenic in ground water. Science 296: 2143-2145. [Crossref]

21. LeBlanc MS, McKinney EC, Meagher RB, Smith AP (2013) Hijacking membrane transporters for arsenic phytoextraction. J Biotechnol 163: 1-9. [Crossref]

22. Williams PN, Villada A, Deacon C, Raab A, Figuerola J, et al. (2007) Greatly enhanced arsenic shoot assimilation in rice leads to elevated grain levels compared to wheat and barley. Environ Sci Technol 41(19): 6854-6859. [Crossref]

23. Li N, Wang J, Song WY2 (2016) Arsenic uptake and translocation in plants. Plant Cell Physiol 57: 4-13. [Crossref]

24. Cottingham KL, Karimi R, Gruber JF, Zens MS, Sayarath V, et al. (2013) Diet and toenail arsenic concentrations in a New Hampshire population with arsenic-containing water. Nutr J 12(149). [Crossref]

25. Oguri T, Yoshinaga J, Tao H, Nakazato T (2014) Inorganic arsenic in the Japanese diet daily intake and source. Arch Environ Contam Toxicol 66: 100-112. [Crossref]

26. Clowes LA, Francesconi KA (2004) Uptake and elimination of arsenobetaine by the mussel Mytilus edulis is related to salinity. Comp Biochem Physiol C Toxicol Pharmacol 137: 35-42. [Crossref]

27. Fattorini D, Notti A, Regoli F. 2006. Characterization of arsenic content in marine organisms from temperate, tropical, and polar environments. Chem Ecol 22: 405-414.

28. Rossman T. 2007. Arsenic. In: Rom W and Markowitz S Eds. Environmental and occupational medicine, 4th ed. Hagerstown, MD: Lippincott Williams \& Wilkins. pp. 1006-1017

29. Bhattacharjee H, Rosen BP, Mukhopadhyay R. 2009. Aquaglyceroporins and metalloid transport: implications in human diseases. Handbook of Experimental Pharmacology 190: $309-325$

30. Rosenberg H, Gerdes RG, Chegwidden K (1977) Two systems for the uptake of phosphate in Escherichia coli. J Bacteriol 131: 505-511. [Crossref]

31. Bun-ya M, Shikata K, Nakade S, Yompakdee C, Harashima S, et al. (1996) Two new genes, PHO86 and PHO87, involved in inorganic phosphate uptake in Saccharomyces cerevisiae. Curr Genet 29: 344-351. [Crossref]

32. Sanders OI, Rensing C, Kuroda M, Mitra B, Rosen BP (1997) Antimonite is accumulated by the glycerol facilitator GlpF in Escherichia coli. J Bacteriol 179: 3365 3367. [Crossref]

33. Wysocki R, Chéry CC, Wawrzycka D, Van Hulle M, Cornelis R, et al. (2001) The glycerol channel Fpslp mediates the uptake of arsenite and antimonite in Saccharomyces cerevisiae. Mol Microbiol 40: 1391-1401. [Crossref]

34. Liu Z, Shen J, Carbrey JM, Mukhopadhyay R, Agre P, et al. (2002) Arsenite transport by mammalian aquaglyceroporins AQP7 and AQP9. Proc Natl Acad Sci U S A 99: 6053-6058. [Crossref]

35. Hughes MF (2002) Arsenic toxicity and potential mechanisms of action. Toxicol Lett 133: 1-16. [Crossref]

36. Rossman TG (2003) Mechanism of arsenic carcinogenesis: an integrated approach Mutat Res 533: 37-65. [Crossref]

37. Willsky GR, Bennett RL, Malamy MH. (1973) Inorganic phosphate transport in Escherichia coli: involvement of two genes which play a role in alkaline phosphatase regulation. J Bacteriol 113(2): 529-539. [Crossref]

38. Willsky GR, Malamy MH (1980) Effect of arsenate on inorganic phosphate transport in Escherichia coli. J Bacteriol 144: 366-374. [Crossref]

39. Rosen BP, Liu Z (2009) Transport pathways for arsenic and selenium: a minireview Environ Int 35: 512-515. [Crossref]

40. Bertin PN, Heinrich-Salmeron A, Pelletier E, Goulhen-Chollet F, Arsene-Ploetze F, et al. (2011) Metabolic diversity among main microorganisms inside an arsenic-rich ecosystem revealed by meta- and proteo-genomics. ISME J 5: 1735-1747.. [Crossref]

41. Nagarajan VK, Jain A, Poling MD, Lewis AJ, Raghothama KG, et al. (2011) Arabidopsis Pht 1;5 mobilizes phosphate between source and sink organs and influences the interaction between phosphate homeostasis and ethylene signaling. Plant Physiol 156: 1149-1163. [Crossref] 
42. Karthikeyan AS1, Varadarajan DK, Mukatira UT, D’Urzo MP, Damsz B, et al. (2002) Regulated expression of Arabidopsis phosphate transporters. Plant Physiol 130: 221233. [Crossref]

43. Mudge SR, Rae AL, Diatloff E, Smith FW. (2002) Expression analysis suggests novel roles for members of the Pht 1 family of phosphate transporters in Arabidopsis. Plant $J$ 31: 341-353.. [Crossref]

44. Shin H, Shin HS, Dewbre GR, Harrison MJ (2004) Phosphate transport in Arabidopsis: $\mathrm{Pht} 1 ; 1$ and Pht $1 ; 4$ play a major role in phosphate acquisition from both low- and highphosphate environments. Plant J 39: 629-642. [Crossref]

45. Remy E, Cabrito TR, Batista RA, Teixeira MC, Sa-Correia I, et al. 2012. The Pht1;9 and $\mathrm{Pht} 1 ; 8$ transporters mediate inorganic phosphate acquisition by the Arabidopsis thaliana root during phosphorus starvation. New Phytol 195: 356-371.

46. Castrillo G, Sanchez-Bermejo E, de Lorenzo L, Crevillen P, Fraile-Escanciano, et al. (2013) WRKY6 transcription factor restricts arsenate uptake and transposon activation in Arabidopsis. Plant Cell 25: 2944-2957. DOI: 10.1105/tpc.113.114009. [Crossref]

47. Wang H, Xu Q, Kong YH, Chen Y, Duan JY, et al. (2014) Arabidopsis WRKY45 transcription factor activates Phosphate Transporter1;1 expression in response to phosphate starvation. Plant Physiol 164: 2020-2029. [Crossref]

48. Gonzalez E, Solano R, Rubio V, Leyva A, Paz-Ares J. (2005) Phosphate Transporter Traffic Facilitator1 is a plants specific SEC12-related protein that enables the endoplasmic reticulum exit of a high-affinity phosphate transporter in Arabidopsis. Plant Cell 17: 3500-3512. [Crossref]

49. Ma LQ, Komar KM, Tu C, Zhang W, Cai Y, et al. (2001) A fern that hyperaccumulates arsenic. Nature 409: 579. [Crossref]

50. Rausch C, Bucher M (2002) Molecular mechanisms of phosphate transport in plants. Planta 216: 23-37. [Crossref]

51. Di Tusa SF, Fontenot EB, Wallace RW, Silvers, MA, Steele TN, et al. (2016) A member of the Phosphate transporter 1 (Pht1) family from the arsenic-hyperaccumulating fern Pteris vittata is a high-affinity arsenate transporter. New Phytol 209: 762-772. [Crossref]

52. Ullrich-Eberius CI, Sanz A, Novacky AJ. 1989. Evaluation of arsenate-andvanadateassociated changes of electrical membrane potential and phosphate transport in Lemna gibba-G1. J Exp Bot 40: 119-128.

53. Meharg AA, Macnair MR. (1992) Suppression of the high affinity phosphate uptake system: a mechanism of arsenate tolerance in Holcus lanatus L. J Exp Bot 43: 519-524.

54. Clark GT, Dunlop J, Phung HT. (2003) Phosphate absorption by Arabidopsis thaliana: interactions between phosphorus status and inhibition by arsenate. Aust J Plant Physiol 27: 959-965.

55. Esteban E, Carpena RO, Meharg AA. (2003) High affinity phosphate/arsenate transport in white lupin (Lupinus albus) is relatively insensitive to phosphate status. New Phytol 158: $165-173$

56. Tu C, Ma LQ. 2003. Interactive effects of $\mathrm{pH}$, arsenic and phosphorus on uptake of As and $\mathrm{P}$ and growth of the arsenic hyperaccumulator Pteris vittata $L$. under hydroponic conditions. Environ Exp Bot 50: 243-251.

57. Wang JR, Zhao FJ, Meharg AA, Raab A, Feldmann J, et al. (2002) Mechanisms of arsenic hyperaccumulation in Pteris vittata. Uptake kinetics, interactions with phosphate, and arsenic speciation. Plant Physiol 130: 1552-1561. [Crossref]

58. Bleeker PM, Schat H, Vooijs R, Verkleij JAC, Ernst,WHO. (2003) Mechanisms of arsenate tolerance in Cytisus striatus. New Phytol 157: 33-38.

59. Jia H, Ren H, Gu M, Zhao J, Sun S, et al. (2011) The phosphate transporter gene OsPht $1 ; 8$ is involved in phosphate homeostasis in rice. Plant Physiol 156: 1164-1175. [Crossref]

60. Wu Z, Ren H, McGrath SP, Wu P, Zhao FJ (2011) Investigating the contribution of the phosphate transport pathway to arsenic accumulation in rice. Plant Physiol 157: 498-508. [Crossref]

61. Sun SB, Gu M, Cao Y, Huang XP, Zhang X, et al. (2012) A constitutive expressed phosphate transporter, OsPht1;1, modulates phosphate uptake and translocation in phosphate-replete rice. Plant Physiol 159: 1571-1581. [Crossref]

62. Kamiya T, Islam MR, Duan GL, Uraguchi S, Fujiwara T. 2013 Phosphate deficiency signaling pathway is a target of arsenate and phosphate transporter OsPT1 is involved in As accumulation in shoots of rice. Soil Sci Plant Nutr 59: 580-590.

63. Catarecha P, Segura MD, Franco-Zorrilla JM, García-Ponce B, Lanza M, et al. (2007) A mutant of the Arabidopsis phosphate transporter PHT1;1 displays enhanced arsenic accumulation. Plant Cell 19(3): 1123-1133. [Crossref]
64. Mendoza-Cózatl DG, Jobe TO, Hauser F, Schroeder JI. (2011) Long-distance transport, vacuolar sequestration, tolerance, and transcriptional responses induced by cadmium and arsenic. Curr Opin Plant Biol. 14: 554-562. [Crossref]

65. Finnegan PM, Chen W (2012) Arsenic toxicity: the effects on plant metabolism. Front Physiol 3: 182. [Crossref]

66. Palmieri L,Picault N, Arrigoni R, Besin E, Palmieri F. et al. (2008) Molecular identification of three Arabidopsis thaliana mitochondrial dicarboxylate carrier isoforms: organ distribution, bacterial expression, reconstitution into liposomes and functional characterization. Biochem J 410: 621-629(part 3). [Crossref]

67. Lomax C, Liu WJ, Wu L, Xue K, Xiong J, et al. (2012) Methylated arsenic species in plants originate from soil microorganisms. New Phytol 193: 665-672. [Crossref]

68. Dhankher OP, Li YJ, Rosen BP, Shi J, Salt D, et al. (2002) Engineering tolerance and hyperaccumulation of arsenic in plants by combining arsenate reductase and gammaglutamylcysteine synthetase expression. Nat Biotechnol 20: 1140-1145. [Crossref]

69. Pickering IJ, Prince RC, George MJ, Smith RD, George GN, et al. (2000) Reduction and coordination of arsenic in Indian mustard. Plant Physiol 122: 1171-1177. [Crossref]

70. Xu XY, McGrath SP, Zhao FJ (2007) Rapid reduction of arsenate in the medium mediated by plant roots. New Phytol 176: 590-599. [Crossref]

71. Bhattacharjee H, Rosen BP. (2007). Arsenic metabolism in prokaryotic and eukaryotic microbes. In: Nies DH, Silver S, eds. Molecular microbiology of heavy metals. Berlin, Germany: Springer-Verlag, 371-406.

72. Meng YL, Liu Z, Rosen BP (2004) As(III) and Sb(III) uptake by GlpF and efflux by ArsB in Escherichia coli. J Biol Chem 279: 18334-18341. [Crossref]

73. Liu JX, Zhou GB, Chen SJ, Chen Z (2012) Arsenic compounds: revived ancient remedies in the fight against human malignancies. Curr Opin Chem Biol 16: 92-98. [Crossref]

74. Agre P. (2004) Aquaporin water channels (Nobel lecture). Angew Chem Int Edit 43 4278-4290. [Crossref]

75. Wallace IS, Choi WG, Roberts DM (2006) The structure, function and regulation of the nodulin 26-like intrinsic protein family of plant aquaglyceroporins. Biochim Biophys Acta 1758: 1165-1175. [Crossref]

76. Bienert GP, Thorsen M, Schüssler MD, Nilsson HR, Wagner A, et al. (2008) A subgroup of plant aquaporins facilitate the bidirectional diffusion of $\mathrm{As}(\mathrm{OH}) 3$ and $\mathrm{Sb}(\mathrm{OH}) 3$ across membranes. BioMedCentral Biology 6: 26. [Crossref]

77. Isayenkov SV, Maathuis FJM. 2008. The Arabidopsis thaliana aquaglyceroporin AtNIP7;1 is a pathway for arsenite uptake. FEBS Lett 582: 1625-1628.

78. Ma JF, Yamaji N, Mitani N, Xu XY, Su YH, et al. (2008) Transporters of arsenite in rice and their role in arsenic accumulation in rice grain. Proc Natl Acad Sci U S A 105 9931-9935. [Crossref]

79. Yang HC, Cheng J, Finan TM, Rosen BP, Bhattacharjee H. (2005) Novel pathway for arsenic detoxification in the legume symbiont Sinorhizobium meliloti. J Bacteriol 187: 6991-6997. [Crossref]

80. Messens J, Silver S (2006) Arsenate reduction: thiol cascade chemistry with convergent evolution. J Mol Biol 362: 1-17. [Crossref]

81. Meharg AA, Jardine L. 2003. Arsenite transport into paddy rice (Oryza sativa) roots. New Phytol 157: 39-44.

82. Chaumont F, Moshelion M, Daniels MJ (2005) Regulation of plant aquaporin activity. Biol Cell 97: 749-764. [Crossref]

83. Maurel C, Verdoucq L, Luu DT, Santoni V. 2008. Plant aquaporins: membrane channels with multiple integrated functions. Annual Review of Plant Biology 59: 595-624.

84. Kamiya T, Tanaka M, Mitani N, Ma JF, Maeshima M. et al. 2009. NIP1;1, an aquaporin homolog, determines the arsenite sensitivity of Arabidopsis thaliana. J Biol Chem 284: 2114-2120.

85. Xu W, Dai W, Yan H, Li S, Shen H, et al. (2015) Arabidopsis NIP3;1 plays an important role in arsenic uptake and root-to-shoot translocation under arsenite stress conditions. Mol Plant 8: 722-733. [Crossref]

86. Zhu YG, Williams PN, Meharg AA (2008) Exposure to inorganic arsenic from rice: a global health issue? Environ Pollut 154: 169-171. [Crossref]

87. Ali W, Isner JC, Isayenkov SV, Liu WJ, Zhao FJ, et al. (2012) Heterologous expression of the yeast arsenite efflux system ACR3 improves Arabidopsis thaliana tolerance to arsenic stress. New Phytol 194: 716-723. [Crossref]

88. Katsuhara M, Sasano S, Horie T, Matsumoto T, Rhee J, et al. 2014. Functional 
and molecular characteristics of rice and barley NIP aquaporins transporting water, hydrogen peroxide and arsenite. Plant Biotechnology 31: 213-219.

89. Ma JF, Tamai K, Yamaji N, Mitani N, Konishi S, et al. (2006) A silicon transporter in rice. Nature 440: 688-691. [Crossref]

90. Ma JF, Yamaji N, Mitani N, Tamai K, Konishi S, et al. (2007) An efflux transporter of silicon in rice. Nature 448: 209-212. [Crossref]

91. Srivastava S, Akkarakaran JJ, Sounderajan S, Shrivastava M, Suprasanna P (2016) Arsenic toxicity in rice (Oryza sativa L.) is influenced by sulfur supply: Impact on the expression of transporters and thiol metabolism. Geoderma 270: 33-42.

92. Zhang J, Zhao CY, Liu J, Song R, Du YX, et al. 2016. Influence of sulfur on transcription of genes involved in arsenic accumulation in rice grains. Plant MolBio Rep 34: 556-565.

93. Chen Z, Zhu YG, Liu WJ, Meharg AA (2005) Direct evidence showing the effect of root surface iron plaque on arsenite and arsenate uptake into rice (Oryza sativa) roots. New Phytol 165: 91-97. [Crossref]

94. Seyfferth AL, Webb SM, Andrews JC, Fendorf S (2010) Arsenic localization, speciation, and co-occurrence with iron on rice (Oryza sativa L.) roots having variable Fe coatings. Environ Sci Technol 44: 8108-8113. [Crossref]

95. Hansel CM, La Force MJ, Fendorf S, Sutton S (2002) Spatial and temporal association of As and Fe species on aquatic plant roots. Environ Sci Technol 36: 1988-1994. [Crossref]

96. Blute NK, Brabander DJ, Hemond HF, Sutton SR, Newville MG, et al. (2004) Arsenic sequestration by ferric iron plaque on cattail roots. Environ Sci Technol 38: 6074-6077. [Crossref]

97. Liu WJ, Zhu YG, Smith FA, Smith SE (2004) Do phosphorus nutrition and iron plaque alter arsenate (As) uptake by rice seedlings in hydroponic culture? New Phytol 162: 481-488.

98. Liu Z, Carbrey JM, Agre P, Rosen BP (2004) Arsenic trioxide uptake by human and rat aquaglyceroporins. Biochem Biophys Res Commun 316: 1178-1185. [Crossref]

99. Zhao FJ, Ma JF, Meharg AA, McGrath SP (2009) Arsenic uptake and metabolism in plants. New Phytol 181: 777-794. [Crossref]

100. Mosa KA, Kumar K, Chhikara S, Mcdermott J, Liu Z, et al. (2012) Members of rice plasma membrane intrinsic proteins subfamily are involved in arsenite permeability and tolerance in plants. Transgenic Res 21(6): 1265-1277. [Crossref]

101. Liu Z, Boles E, Rosen BP (2004) Arsenic trioxide uptake by hexose permeases in Saccharomyces cerevisiae. J Biol Chem 279: 17312-17318. [Crossref]
102. Zhao FQ, Keating AF (2007) Functional properties and genomics of glucose transporters. Curr Genomics 8: 113-128. [Crossref]

103. KC S, Cárcamo JM, Golde DW. (2005) Vitamin C enters mitochondria via facilitative glucose transporter 1 (Glut1) and confers mitochondrial protection against oxidative injury. FASEB J. 19(12): 1657-1667. DOI: 10.1096/fj.05-4107com. [Crossref]

104. Liu Z, Sanchez MA, Jiang X, Boles E, Landfear SM, et al. (2006) Mammalian glucose permease GLUT1 facilitates transport of arsenic trioxide and methylarsonous acid. Biochem Biophys Res Commun 351: 424-430. [Crossref]

105. Liu Z, Styblo M, Rosen BP (2006) Methylarsonous acid transport by aquaglyceroporins. Environ Health Perspect 114: 527-531. [Crossref]

106. Rahman MA, Kadohashi K, Maki T, Hasegawa H. 2011. Transport of DMAA and MMAA into rice (Oryza sativa L.) roots. Environ Exp Bot 72: 41-46.

107. Zheng M, Li G, Sun GX, Shim H, Cai C. 2013 Differential toxicity and accumulation of inorganic and methylated arsenic in rice. Plant Soil 365(1-2): 227-238.

108. Li RY, Ago Y, Liu WJ, Mitani N, Feldmann J, et al. (2009) The rice aquaporin Lsi1 mediates uptake of methylated arsenic species. Plant Physiol 150: 2071-2080. [Crossref]

109. Hu H, Zhang J, Wang H, Li R, Pan F, et al. (2013) Effect of silicate supplementation on the alleviation of arsenite toxicity in 93-11 (Oryza sativa L. indica). Environ Sci Pollut Res Int 20: 8579-8589. [Crossref]

110. Tripathi P, Tripathi RD, Singh RP, Dwivedi S, Goutam D, et al. 2013. Silicon mediate arsenic tolerance in rice (Oryza sativa L.) through lowering of arsenic uptake and improved antioxidant defence system. Ecol Eng 52: 96-103.

111. Liu WJ, McGrath SP, Zhao FJ. 2014. Silicon has opposite effects on the accumulation of inorganic and methylated arsenic species in rice. Plant Soil 376(1-2): 423-431. DOI: $10.1007 / \mathrm{s} 11104-013-1991-7$

112. Uldry M, Ibberson M, Hosokawa M, Thorens B (2002) GLUT2 is a high affinity glucosamine transporter. FEBS Lett 524: 199-203. [Crossref]

113. Vera JC, Rosen OM (1989) Functional expression of mammalian glucose transporter in Xenopus laevis oocytes: evidence for cell-dependent insulin sensitivity. Mol Cell Biol 9: 4187-4195. [Crossref]

114. McDermott JR, Jiang X, Beene LC, Rosen BP, Liu Z. (2010) Pentavalent methylated arsenicals are substrates of human AQP9. Biometals. 23(1):119-127. DOI: 10.1007/ s10534-009-9273-9. [Crossref]

115. Rosen BP (2002) Biochemistry of arsenic detoxification. FEBS Lett 529: 86-92. [Crossref]

Copyright: (C2016 Kowalczyk A. This is an open-access article distributed under the terms of the Creative Commons Attribution License, which permits unrestricted use, distribution, and reproduction in any medium, provided the original author and source are credited. 